\title{
Coleus barbatus: UM NOVO HOSPEDEIRO DE Ralstonia solanacearum
}

\author{
R.A. COELHO NETTO \& L.A.G. ASSIS
}

Instituto Nacional de Pesquisa da Amazônia, Coordenação de Pesquisa em Ciências Agronômicas, Cx. Postal 478, CEP 69011-670, Manaus, AM, e-mail: rcoelho@inpa.gov.br

(Aceito para publicação em 18/09/2001)

Autor para correspondência: Rosalee A. Coelho Netto

\section{ABSTRACT \\ Coleus barbatus: a new Ralstonia solanacearum host}

Coleus barbatus commonly known as "false boldo" belongs to the family of the Laminaceae and has cardiotonic and analgesic properties. Plants of $C$. barbatus developing wilt symptoms were observed in a domestic garden located in Manaus, AM, Brazil. A vascular pathogen was isolated and identified as Ralstonia solanacearum, biovar N2, race 1 . The inoculation of healthy $C$. barbatus plants produced the symptoms observed in the field, and the bacterium was reisolated. The bacterium strains isolated caused wilt in tomato (Lycopersicon esculentum), potato (Solanum tuberosum), sweet pepper (Capsicum annuum) and eggplant (Solanum melongena) and necrosis in cucumber (Cucumis sativus) plants. The strains were not pathogenic to banana (Musa sp.) plants. This is the first report of bacterial wilt in C. barbatus
Coleus barbatus (Andr.) Benth (C. forskohlii), popularmente conhecido como falso boldo, é um subarbusto perene, aromático, com caule ereto e piloso, folhas ovais, pilosas, com bordos crenados. A espécie pertence à família Lamiaceae e tem sido amplamente utilizada em diversos países pelas suas propriedades analgésicas, anti-hipertensivas e antidiarréicas. Coleus barbatus é, ainda, a única fonte conhecida de forskolin, uma importante droga utilizada no tratamento de glaucoma, cardiopatias e asma (Suryanarayanan et al. J. Med. Arom. Pl. Sci. 20:379, 1998). Plantas de C. barbatus, provenientes de uma horta caseira no município de Manaus, AM, apresentando sintomas de murcha e escurecimento vascular foram examinadas no Laboratório de Fitopatologia do INPA. Após testes positivos de exsudação bacteriana em água, fragmentos do caule foram utilizados para isolamento da bactéria em meio semi-seletivo, contendo cloreto de 2, 3, 5 trifenil tetrazólium (Kelman, A. Phytopathology 44:693-695, 1954). As colônias da bactéria isolada apresentaram crescimento fluido e coloração branco-creme com a área central vermelho-rosada. Colônias individuais foram transferidas para meio LPGA (Kpémova et al. Can. J. Microbiol. 42:1131-1143, 1996) e duas subculturas, provenientes de plantas distintas, foram utilizadas para testes de hipersensibilidade em folhas de fumo (Nicotiana benthamiana L.), e de patogenicidade, em plantas sadias de C. barbatus. Para o teste de patogenicidade foram utilizadas três mudas de C. barbatus, para cada isolado. Para inoculação, depositou-se uma gota de suspensão bacteriana $\left(1 \times 10^{8}\right.$ ufc/ $\mathrm{ml}$ ) em uma axila foliar e, com uma agulha, foram realizadas perfurações no tecido da planta, sob a gota. Para as plantas testemunha utilizou-se água destilada estéril, em substituição à suspensão bacteriana. Dois dias após, as plantas inoculadas com a suspensão bacteriana, apresentavam sintomas de murcha. Os sintomas evoluíram causando descoloração vascular e morte das plantas. A bactéria pode ser reisolada, completando-se os postulados de Koch.

Para determinação da raça, as estirpes foram também inoculadas em tomateiros (Lycopersicon esculentum Mill.) cv. Santa Cruz, em plantas de batata (Solanum tuberosum L.) cv. Monalisa, de berinjela (Solanum melongena L.) cv. Embu, de pepino (Cucumis sativus L.) cv. Verde Comprido e de pimentão (Capsicum annuum L.) cv. Yolo Wonder seguindose a mesma metodologia usada no teste de patogenicidade. Mudas de bananeira (Musa sp.) cv. Prata-anã foram inoculadas injetando-se $1 \mathrm{ml}$ de suspensão bacteriana $\left(1 \times 10^{8} \mathrm{ufc} /\right.$ $\mathrm{ml}$ ), na base do pseudocaule. Para cada espécie, utilizaramse três vasos com três plantas ou, no caso da bananeira, três mudas, para inocular cada uma das estirpes e mais três vasos (ou mudas) para as testemunhas. Todas as espécies inoculadas com a bactéria, excetuando-se as bananeiras e as plantas de pepino, apresentaram sintomas de murcha. As plantas de pepino apresentaram necrose, a partir do ponto de inoculação, se estendendo por alguns centímetros na direção do caule e da folha. Plantas de C. barbatus foram inoculadas utilizandose a mesma metodologia usada para o teste de patogenicidade, com três estirpes de Ralstonia solanacearum Smith provenientes de tomateiros e pertencentes aos biovares I, II e III e com uma estirpe, proveniente de bananeira (biovar I). Apenas as plantas inoculadas com estirpes isoladas de tomateiros, apresentaram sintomas de murcha.

Com base em testes bioquímicos propostos por Hayward (Ann. Rev. Phytopath. 29:65, 1991) concluiu-se tratar-se de $R$. solanacearum biovar N2, raça 1. Este constituise, provavelmente, o primeiro relato de C. barbatus como hospedeiro de $R$. solanacearum. 